\title{
Implication of Ions and Organic Solutes Accumulation in Amaranth (Amaranthus cruentus L.) Salinity Resistance
}

\author{
Agapit Wouyou', Hermann Prodjinoto",2, Ahissou Séraphin Zanklan1, \\ Brigitte Vanpee $^{2}$, Stanley Lutts ${ }^{2}$, Christophe Bernard Gandonou ${ }^{{ }^{*}}$
}

\author{
${ }^{1}$ Unité de Recherche sur l'Adaptation des Plantes aux Stress Abiotiques, les Métabolites Secondaires et l'Amélioration des \\ Productions Végétales, Laboratoire de Physiologie Végétale et d'Etude des Stress Environnementaux, Faculté des Sciences et \\ Techniques (FAST/UAC), Tri Postal, Cotonou, Bénin \\ ${ }^{2}$ Groupe de Recherche en Physiologie végétale, Earth and Life Institute, ELI-A, Université Catholique de Louvain, \\ Louvain-La-Neuve, Belgique \\ Email: ${ }^{\star}$ ganchrist@hotmail.com
}

How to cite this paper: Wouyou, A. Prodjinoto, H., Zanklan, A.S., Vanpee, B., Lutts, S. and Gandonou, C.B. (2019) Implication of Ions and Organic Solutes Accumulation in Amaranth (Amaranthus cruentus L.) Salinity Resistance. American Journal of Plant Sciences, 10, 2335-2353. https://doi.org/10.4236/ajps.2019.1012162

Received: August 26, 2019

Accepted: December 28, 2019

Published: December 31, 2019

Copyright $\odot 2019$ by author(s) and Scientific Research Publishing Inc. This work is licensed under the Creative Commons Attribution International License (CC BY 4.0).

http://creativecommons.org/licenses/by/4.0/

\begin{abstract}
Salinity is one of the major environmental constraints limiting agricultural productivity in the world. The effects of salt stress on growth, ions and organic solutes accumulation were investigated in two amaranth (Amaranthus cruentus) cultivars: Rouge (salt-resistant) and Locale (salt-sensitive). Young plants of these cultivars were exposed, in hydroponic system, to three concentrations of $\mathrm{NaCl}:$ 0, 30 and $90 \mathrm{mM}$. Growth parameters, ions, free proline and soluble sugars concentrations were determined after 2 weeks of stress. $\mathrm{NaCl}$ effect resulted in plant growth reduction in both cultivars but plants of cultivar Rouge were less affected compared to that of $\mathrm{cv}$. Locale. $\mathrm{Na}^{+}$, proline and soluble sugars concentrations increased significantly in leaves and roots under salinity while $\mathrm{K}^{+}, \mathrm{Ca}^{2+}$ and $\mathrm{Mg}^{2+}$ concentrations decreased in both cultivars. Proline and soluble sugars increased significantly in leaves and roots of cultivar Locale whereas in cultivar Rouge, proline increase was significant only in roots and soluble sugars increase was significant only in leaves. The highest increase of $\mathrm{Na}^{+}$concentration occurred in leaves of cv. Rouge coupled with the lowest reduction in $\mathrm{K}^{+}$concentration. The highest increase of proline occurred in leaves of cultivar Locale whereas the highest increase of soluble sugars was observed in leaves of cultivar Rouge. The reduction of the $\mathrm{Ca}^{2+}$ concentration under salt stress was more accentuated in both leaves and roots of cultivar Rouge than cultivar Locale while cv. Rouge maintained higher content in $\mathrm{Mg}^{2+}$ either in leaves or in roots in the presence of $\mathrm{NaCl}$ than cultivar Locale. These results suggest an implication of $\mathrm{Na}^{+}, \mathrm{K}^{+}$and $\mathrm{Mg}^{2+}$ in salt
\end{abstract}


resistance in these cultivars and that soluble sugars may play an important role in salt-resistance in Amaranthus cruentus. However, proline appears as a symptom of injury in stressed plants rather than an indicator of resistance.

\section{Keywords}

Growth, Ions Concentration, Osmolytes Accumulation, Amaranthus cruentus, Salt-Resistance Mechanism

\section{Introduction}

Salt stress is one of the major environmental constraints limiting affecting plant growth, development, and crop productivity [1] [2]. Plant growth is compromised by salinity at all developmental stages, but sensitivity varies greatly at different stages [3] [4] [5]. This complex abiotic stress affects osmotic and ionic properties and induces a wide range of metabolic perturbations in higher plants altering many physiological and biochemical processes such as mineral nutrition, respiration rate, organic solutes/osmolyte synthesis, seed germination, enzyme activities and photosynthesis [6] [7]. Nevertheless, plants have developed several adaptative mechanisms in order to survive in the presence of salt. These strategies however vary depending on plant species and even, from cultivar to cultivar [8] [9]. Salt tolerance is a complex mechanism, involving tolerance to both the osmotic and ionic stresses caused by high soil salinity [10]. The high salt concentration in plant growth environment commonly induces an increase in cellular concentrations of $\mathrm{Na}^{+}$and $\mathrm{Cl}^{-}$and a decrease of $\mathrm{K}^{+}$concentrations [11] [12] [13] [14] [15]. The regulation of $\mathrm{Na}^{+}$and $\mathrm{Cl}^{-}$uptake is thus essential in order to avoid toxic $\mathrm{Na}^{+}$accumulation in leaves, and to maintain a high $\mathrm{K}^{+} / \mathrm{Na}^{+}$ ratio which is important for the activity of $\mathrm{K}^{+}$-dependent enzymes [16]. In many glycophyte species, such as rice, wheat, cotton and Lotus genotypes, $\mathrm{Na}^{+}$exclusion from growing tissues (leaves or calli) has been shown to promote salt tolerance [13] [17] [18] [19] [20] [21]. However, for other plants, salt-tolerance is associated with inclusion of these toxic ions; thus more tolerant types are those which accumulate more toxic ions (mainly $\mathrm{Na}^{+}$) in growing and photosynthetic tissues. In this category, we can quote sugarcane [22] and lens [23]: in this case, salt-tolerance is directly linked to compartmentation of toxic ions in vacuoles in order to maintain low $\mathrm{Na}^{+}$concentration in the cytosol compatible with enzymatic activities. Furthermore, salt tolerant genotypes maintain a high supply of $\mathrm{K}^{+}$in the presence of an excess of $\mathrm{Na}^{+}$[24] [25]. Considerable interest has been focused on $\mathrm{Ca}^{2+}$ due to its ability to induce a protective effect on plants under adverse environmental conditions. Calcium plays a vital role in salt stress tolerance since it induces antioxidant enzyme activities and reduces lipid peroxidation of cell membranes under abiotic stress [2] [26]. It has also been shown to stabilize cell membrane surfaces, prevent solute leakage from the cytoplasm, maintain normal photosynthesis, regulate the plant hormone metabolism and is directly involved in 
transduction mechanisms [27] [28]. Numerous data suggest that $\mathrm{Na}^{+}$competes with $\mathrm{Ca}^{2+}$ for binding sites under salinity conditions and that apoplastic $\mathrm{Ca}^{2+} \mathrm{di}-$ rectly alleviates symptoms resulting from mineral toxicities [29] [30].

The accumulation of some organic solutes (compatible osmolytes such as proline and non-reducing sugars) also enables plants to tolerate stress effects [10]. Proline and soluble sugars accumulation are frequently reported in plant exposed to salt or water stresses. Cytosolic accumulation of these organic solutes is indeed involved in osmotic adjustment [17] [18] [30] [31]. Proline is also supposed to act as protective agent to enzymes, intracellular structures and cellular homeostasis balance and signaling [32] [33]. The significance of proline accumulation is still a matter of debate and was reported to be a symptom of injury as reported by Lutts et al. [18] and Gandonou et al. [22]. Salt stress also usually results on soluble sugars increase [34] [35]. These solutes could also be involved in osmotic adjustment and tolerant varieties always accumulate more soluble sugars in leaves and growing tissue than sensitive ones [22] [36] [37] [38].

Contrary to several plants such as rice, corn and wheat, little is known about the physiological mechanisms involved in amaranth salt resistance. In Benin, amaranth species are mainly cultivated as leaf vegetable in the cultivable lands of the coastal areas where soil and irrigation water's salinity constitute a major problem hampering crop production. Some studies analyzed salt effects on amaranth seed germination, plant growth and metabolism [39] [40] [41] [42] [43] [44], without however highlighting the physiological mechanisms involved in salt resistance. Data are especially crucially lacking for the species Amaranthus cruentus which is a promising plant species for saline agriculture. In a previous study, we have demonstrated that there is a variability of relative salt-stress resistance among $A$. cruentus cultivars at young plant stage and $c v$. Rouge appeared as the most salt resistant whereas $\mathrm{cv}$. Locale was the most salt sensitive [42]. In the present study, we compared $\mathrm{NaCl}$ effects on growth and $\mathrm{Na}^{+}, \mathrm{K}^{+}$, $\mathrm{Ca}^{2+}, \mathrm{Mg}^{2+}$, proline and soluble sugars accumulation in leaves and roots of plants of two amaranth cultivars which differ in their response to salt stress. Our goal in this study is to analyze the implication of ions and organic solutes accumulation in Amaranthus cruentus salt resistance.

\section{Materials and Methods}

\subsection{Plant Material}

Two Amaranthus cruentus cultivars were used: Locale (salt-sensitive) and Rouge (salt-resistant) according to [42]. Species identification was performed by the team at the National Herbarium of Benin. Cultivars were obtained from the Market Gardening Crops Program of the Benin National Institute for Agricultural Research (INRAB).

\subsection{Experimental Conditions}

Seeds of both the cultivars were germinated in jars filled with substrate (Sub- 
strate NFU 44-551) for a 2 weeks in a greenhouse characterized by a $24 / 22^{\circ} \mathrm{C}$ (day/night) temperature, a 16/8 hours (day/night) photoperiod, a light intensity of $120 \mu$ mole $\cdot \mathrm{m}^{-2} \cdot \mathrm{s}^{-1}$ provided by white fluorescent tubes (F36W/840-T8). The substrate's $\mathrm{pH}\left(\mathrm{H}_{2} \mathrm{O}\right)$ was 6.5 with a conductivity of $40 \mathrm{mS} \cdot \mathrm{m}^{-1}$ and a water retention capacity of $750 \mathrm{ml} \cdot \mathrm{L}^{-1}$. It contained fertitilizer $\left(1 \mathrm{~kg} \cdot \mathrm{m}^{-3}\right)$, dry matter/raw product (50\%) and organic matters/dry product (85\%). The obtained young seedlings were individually transferred in pots containing the same substrate for two further weeks in a same greenhouse. Daytime humidity was set to c.a. $65 \%$. Plants were then transferred to tanks containing a modified Hoagland solution (44) with pH 6. Stress application was carried out after one week on 5-weeks old plants. Treatments consisted in three $\mathrm{NaCl}$ concentrations: 0,30 and $90 \mathrm{mM}$ corresponding to an electrical conductivity of $1.91,4.81$ and $11.70 \mathrm{dS} \cdot \mathrm{m}^{-1}$, respectively. All treatments were repeated three times in a complete randomized design and each repetition consisted in a pooled sample of six plants. Eighteen plants were thus considered per treatment. Salinity stress was maintained over a period of two weeks.

\subsection{Growth Determination}

Plants height (aerial part) was measured before transferring to the media $\left(\mathrm{H}_{0}\right)$; height was measured again after 2 weeks of treatment $\left(\mathrm{H}_{1}\right)$. Relative height growth of plants (RHG) was calculated as $\left(\mathrm{H}_{1}-\mathrm{H}_{0}\right) / \mathrm{H}_{0}$. After 15 days, the plants were harvested. Shoot and root fresh mass were determined. Samples were then transferred to an oven at $80^{\circ} \mathrm{C}$ for 72 hours for dry mass determination. Data in presence of $\mathrm{NaCl}$ were expressed in percentage of that of the control.

\subsection{Mineral Content}

Ions determination was performed according to Prodjinoto et al. [45]. Samples (c.a. $100 \mathrm{mg} \mathrm{DW}$ ) were placed in flask of $10 \mathrm{ml}$ and digested with nitric acid $(68 \%)$ at $80^{\circ} \mathrm{C}$. After complete evaporation, residues were dissolved with nitric acid $\left(\mathrm{HNO}_{3}\right)(68 \%)+\mathrm{HClcc}(1: 3, \mathrm{v} / \mathrm{v})$. Solution was filtered using a layer of Whatman ( $85 \mathrm{~mm}$, Grade 1). The filtrate was used to determine the cations concentration ( $\mathrm{K}, \mathrm{Na}, \mathrm{Mg}$ and $\mathrm{Ca}$ ) by flame emission using atomic absorption spectrometry (Thermo scientific S series model AAS4). The analysis was performed on 3 plants per treatment and each sample was analyzed in triplicate. Results are expressed in $\mathrm{mg} \cdot \mathrm{g}^{-1} \mathrm{DW}$.

\subsection{Extraction and Soluble Solutes Determination}

Proline concentration was determined using the method of Bates et al. [46]. Proline was extracted from organ samples (c.a. $200 \mathrm{mg} \mathrm{FW}$ ) with $10 \mathrm{~mL}$ of $3 \%$ sulphosalicylic acid at $70^{\circ} \mathrm{C}$ for $30 \mathrm{~min}$. After addition of acid ninhydrin and glacial acetic acid to the extracts, the mixture was heated at $90^{\circ} \mathrm{C}$ for $1 \mathrm{~h}$ in water bath. The reaction was then stopped by incubation for $1 \mathrm{~h}$ in an ice bath. The mixture was extracted with toluene and the absorbance of the toluene fraction was spectrophotometrically determined at $520 \mathrm{~nm}$. Proline concentration was deter- 
mined using calibration curve and expressed as $\mu \mathrm{g} \cdot$ proline $^{-1} \mathrm{~g}^{-1} \mathrm{FW}$.

Total soluble sugars were estimated by the anthrone reagent method using glucose as the standard according to [47] as used by Manaa et al. [48]. Soluble sugars concentration was expressed as $\mu \mathrm{g}$ soluble sugars. $\mathrm{g}^{-1} \mathrm{FW}$.

\subsection{Statistical Analysis}

Data are expressed as mean \pm standard error with a reading of three samples per treatment. The analysis of the main effects of stress intensity and/or cultivars was based on a one-way or two-ways analysis of variance (ANOVA). Means were compared using Students, Newman and Keuls test. All statistical analyses were performed using "JMP Pro 12" soft-ware [49].

\section{Results}

\subsection{Plant Growth}

$\mathrm{NaCl}$ stress significantly reduced RHG in the salt-sensitive cultivar Locale (36.6\%) while no reduction was observed in the salt-resistant cultivar Rouge (Table 1). Salt effect induced a significant reduction in shoot and root fresh and dry mass in both cultivars. The average reductions due to $\mathrm{NaCl}$ stress were $30 \%$, $31 \%, 48 \%$ and $34 \%$ for cultivar Locale and only $19 \%, 26 \%, 34 \%$ and $35 \%$ for cultivar Rouge, respectively for shoot fresh mass, shoot dry mass, root fresh mass and root dry mass (Table 1). Thus, except for root dry mass, biomass reduction by $\mathrm{NaCl}$ stress was more accentuated in the salt-sensitive Locale compared to the salt-resistant Rouge.

\subsection{Plant Water Content}

$\mathrm{NaCl}$ stress induced similar effect on shoot water content in both cultivars characterized by slight increase at $30 \mathrm{mM}$ and no effect at $90 \mathrm{mM}$ (Table 2). Thus,

Table 1. Relative Height growth (RHG), shoot fresh mass (SFM), shoot dry mass (SDM), roots fresh mass (RFM) and roots dry mass (RDM) of plants of two amaranth cultivars (Locale, salt-sensitive and Rouge, salt-tolerant) as affected by 30 and $90 \mathrm{mM} \mathrm{NaCl}$ after 2 weeks: Values are expressed as percentages (\%) of means of control plants.

\begin{tabular}{|c|c|c|c|c|c|c|c|c|c|c|}
\hline \multirow{2}{*}{$\begin{array}{l}\mathrm{NaCl} \\
(\mathrm{mM})\end{array}$} & \multicolumn{5}{|c|}{ Cv. Locale } & \multicolumn{5}{|c|}{ Cv. Rouge } \\
\hline & RHG & SFM & SDM & RFM & RDM & RHG & SFM & SDM & RFM & RDM \\
\hline 30 & 85.83 & 83.09 & 78.44 & 64.94 & 71.75 & 122.33 & 95.89 & 81.63 & 76.88 & 79.81 \\
\hline 90 & 40.94 & 56.90 & 59.88 & 38.77 & 60.16 & 81.55 & 66.48 & 65.99 & 54.44 & 50.81 \\
\hline
\end{tabular}

Table 2. Effect of different $\mathrm{NaCl}$ concentrations on shoot water content (\%) of two cultivars of Amaranthus cruentus after two weeks stress application.

\begin{tabular}{ccc}
\hline $\mathrm{NaCl}(\mathrm{mM})$ & Cv. Locale & Cv. Rouge \\
\hline 0 & 86.75 & 86.31 \\
30 & 87.49 & 88.05 \\
90 & 86.05 & 86.43 \\
\hline
\end{tabular}


shoot water content did not change significantly under salt stress in both cultivars.

\subsection{Ion Content}

In the absence of stress, leaves and roots of both cultivars contained similar amounts of $\mathrm{Na}^{+}$and $\mathrm{K}^{+}$in leaves (Figure 1 and Figure 2). For $\mathrm{K}^{+}$in roots and $\mathrm{Mg}^{2+}$ in leaves and in roots, the resistant cultivar Rouge contained more ion than the salt sensitive cultivar Locale in the absence of stress while the sensitive cultivar Locale contained more $\mathrm{Ca}^{2+}$ than the resistant Rouge either in leaves or in roots (Figures 2-4). A dose dependent increase in $\mathrm{Na}^{+}$(Figure 1) concentration was recorded in leaves and in roots while a concomitant decrease was observed for $\mathrm{K}^{+}, \mathrm{Ca}^{2+}$ and $\mathrm{Mg}^{2+}$ concentrations in both cultivars (except $\mathrm{K}^{+}$in leaves at 30 $\mathrm{mM}$ for the resistant cultivar) (Figures 2-4). A two-way ANOVA showed a significant effect of $\mathrm{NaCl}(\mathrm{p}<0.001)$ on $\mathrm{Na}^{+}$concentrations in both cultivars in leaves and in roots; statistical analysis revealed also no significant difference between the two cultivars in leaves and roots $\mathrm{Na}^{+}$concentrations and no interaction between $\mathrm{NaCl}$ concentrations and cultivars (Table 3). However, data revealed that the increase of $\mathrm{Na}^{+}$concentration was more accentuated in the salt resistant

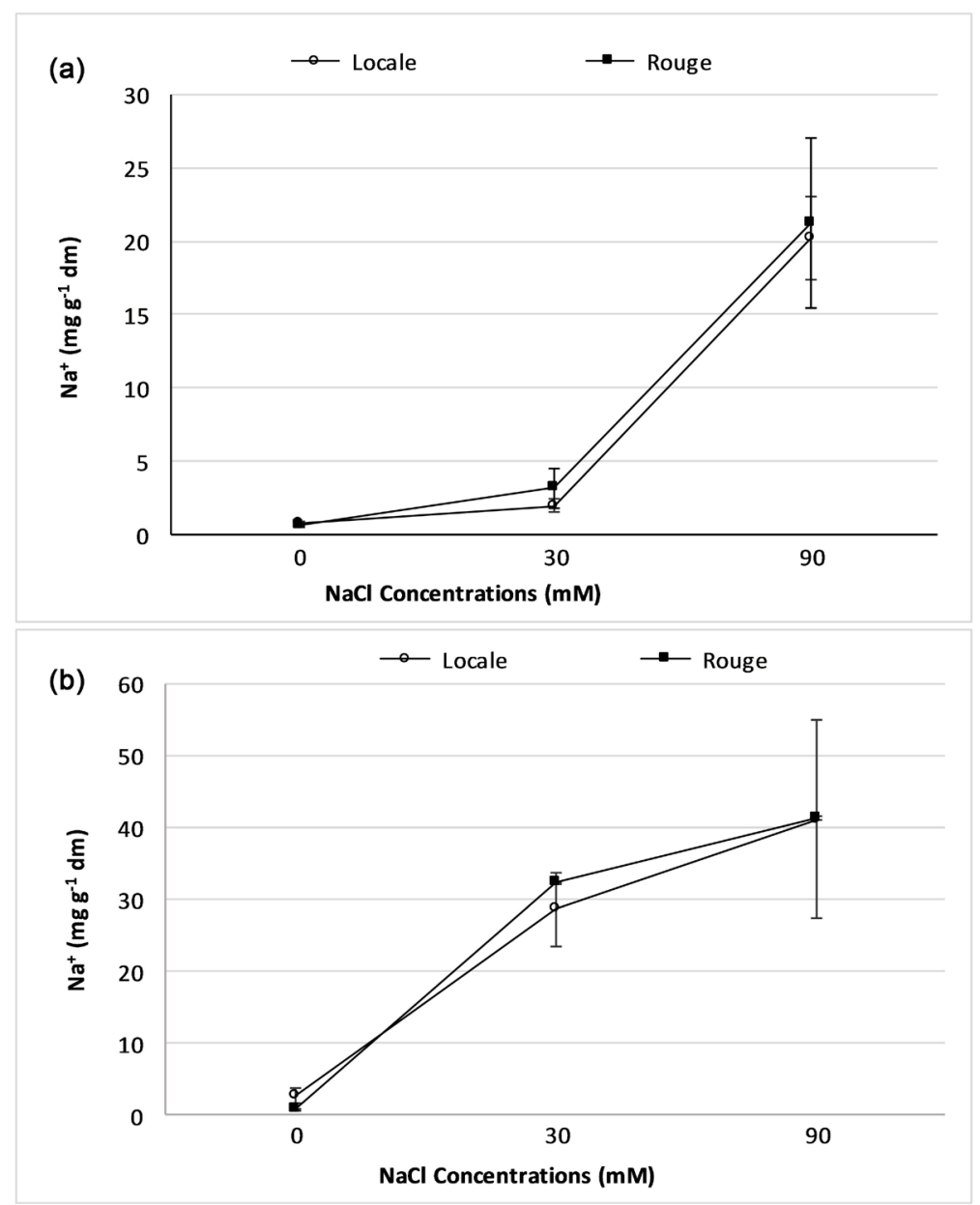

Figure 1. Effect of $\mathrm{NaCl}$ salt stress on sodium ion $\left(\mathrm{Na}^{+}\right)$content in two cultivars of amaranth after 2 weeks: (a) leaves; (b) Roots. 

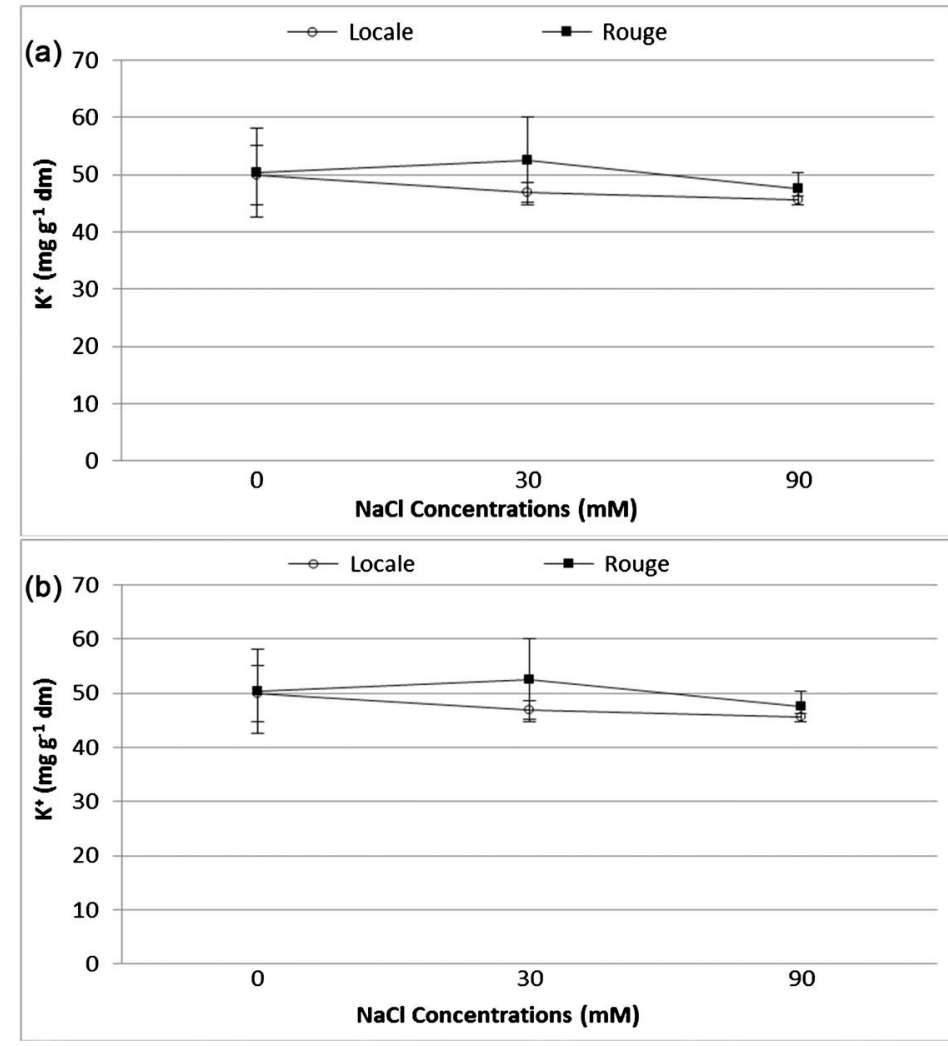

Figure 2. Effect of $\mathrm{NaCl}$ salt stress on potassium ion $\left(\mathrm{K}^{+}\right)$content in two cultivars of amaranth after 2 weeks: (a) leaves; (b) Roots.
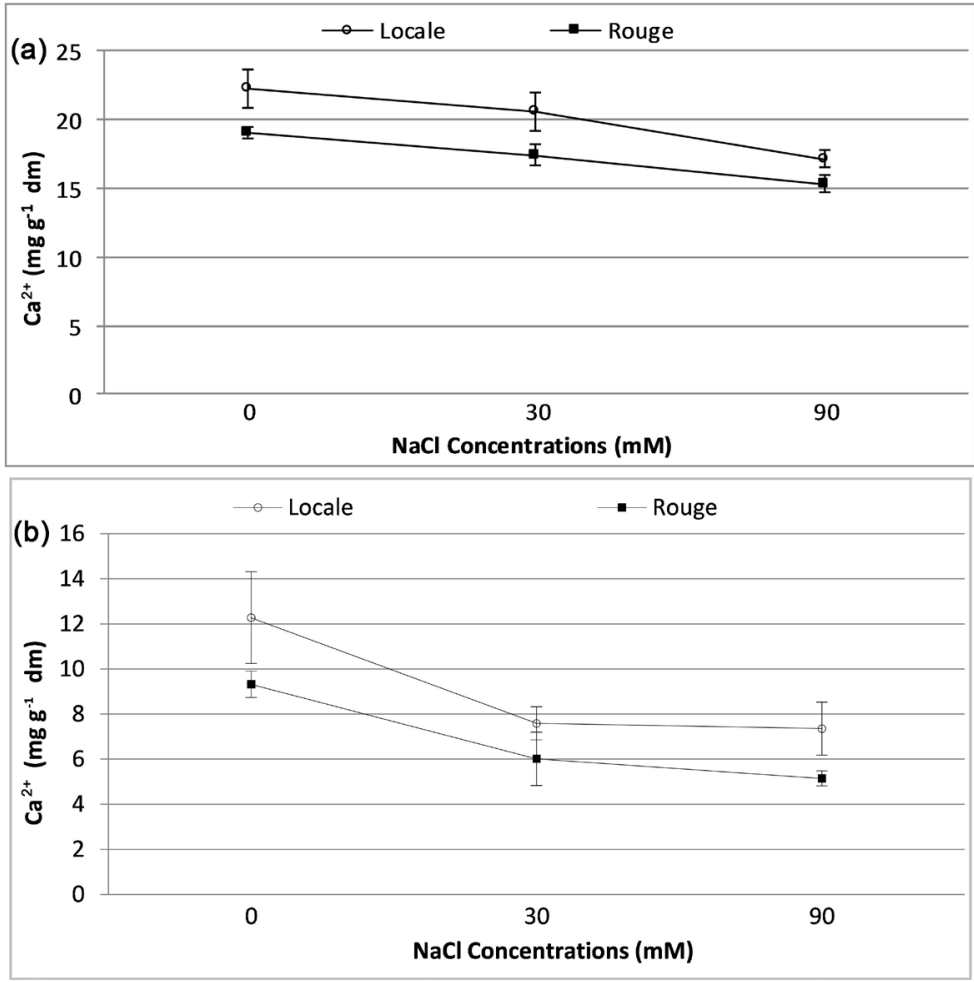

Figure 3. Effect of $\mathrm{NaCl}$ salt stress on calcium ion $\left(\mathrm{Ca}^{2+}\right)$ content in two cultivars of amaranth after 2 weeks: (a) leaves; (b) Roots. 

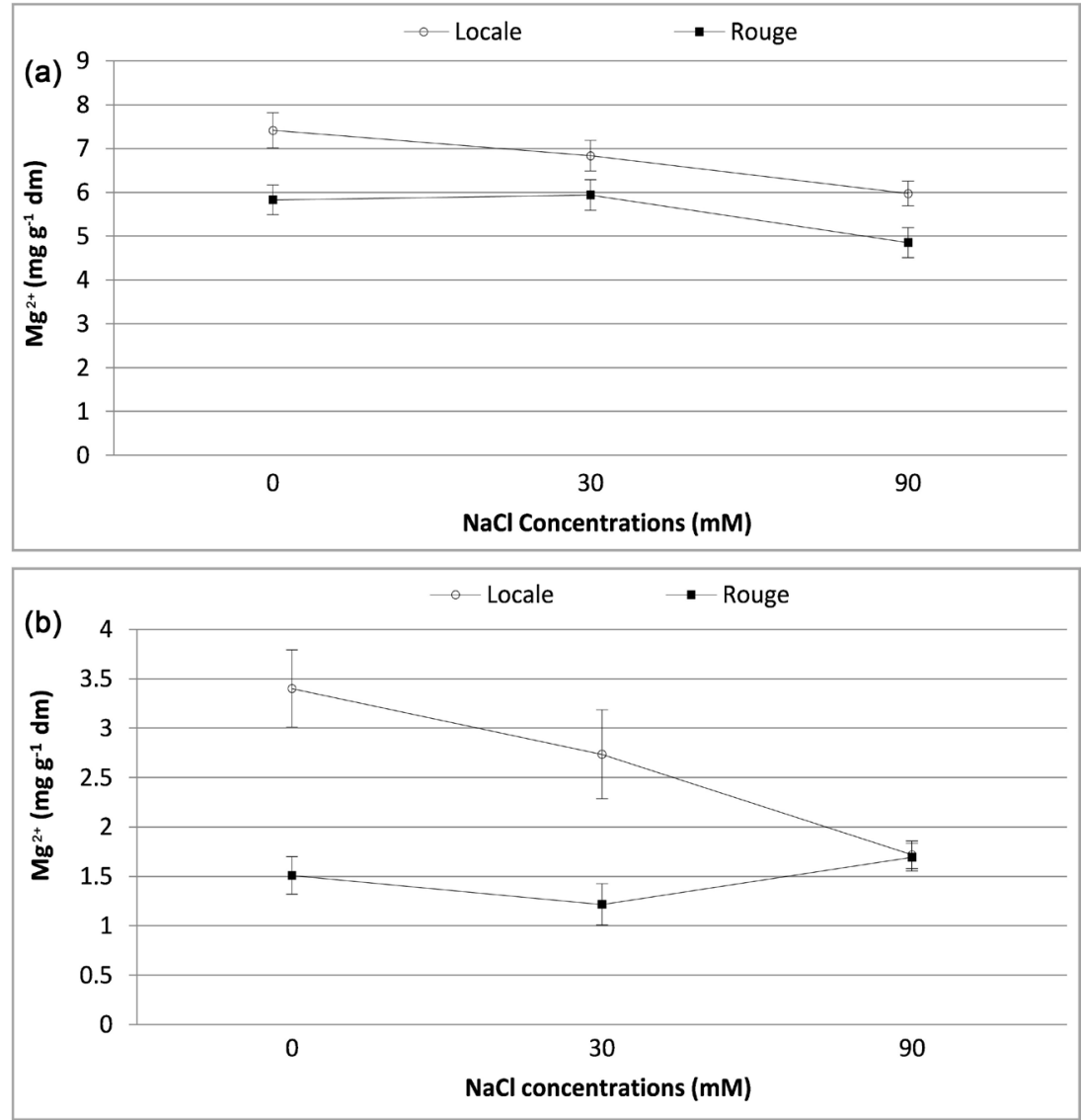

Figure 4. Effect of $\mathrm{NaCl}$ salt stress on magnesium content in two cultivars of amaranth after 2 weeks: (a) leaves; (b) Roots.

Table 3. Results of 2-ways variance analysis for ion content, proline and soluble sugars accumulation of leaves and roots of plants from two cultivars of amaranth; F-ratios are given for the main effects of the following levels of classification: stress intensity (i.e. $\mathrm{NaCl}$ concentration of stressing media), cultivars and interaction between these levels of classification.

\begin{tabular}{|c|c|c|c|c|}
\hline & Paramètres & Stress & Cultivar & Interaction (Stress $\times$ Cultivar) \\
\hline \multirow[t]{2}{*}{$\mathrm{Na}^{+}$} & Leaves & $33.8^{\star * \star}$ & $0.10^{\mathrm{ns}}$ & $0.03^{\text {ns }}$ \\
\hline & Roots & $15.60^{\star * *}$ & $0.01^{\mathrm{ns}}$ & $0.07^{\mathrm{ns}}$ \\
\hline \multirow[t]{2}{*}{$\mathrm{K}^{+}$} & Leaves & $2.03^{\mathrm{ns}}$ & $0.65^{\mathrm{ns}}$ & $0.18^{\mathrm{ns}}$ \\
\hline & Roots & $27.12^{\star \star *}$ & $1.53^{\text {ns }}$ & $0.86^{\mathrm{ns}}$ \\
\hline \multirow[t]{2}{*}{$\mathrm{Ca}^{2+}$} & Leaves & $10.86^{\star *}$ & $12.04^{\star \star}$ & $0.35^{\mathrm{ns}}$ \\
\hline & Roots & $9.29^{* *}$ & $5.71^{\star}$ & $0.18^{\text {ns }}$ \\
\hline \multirow[t]{2}{*}{$\mathrm{Mg}^{2+}$} & Leaves & $6.7^{\star}$ & $17.65^{\star *}$ & $0.51^{\mathrm{ns}}$ \\
\hline & Roots & $3.52^{\text {ns }}$ & $24.06^{* * *}$ & $5.96^{*}$ \\
\hline \multirow[t]{2}{*}{ Proline } & Leaves & $3.69^{\text {ns }}$ & $5.77^{\star}$ & $2.21^{\mathrm{ns}}$ \\
\hline & Roots & $58.25^{\star * \star}$ & $8.36^{*}$ & $7.83^{\star *}$ \\
\hline \multirow[t]{2}{*}{ Soluble sugars } & Leaves & $105.81^{* * *}$ & $9.56^{* *}$ & $1.65^{\mathrm{ns}}$ \\
\hline & Roots & $14.94^{* * *}$ & $7.76^{*}$ & $6.03^{*}$ \\
\hline
\end{tabular}

ns: not significant; ${ }^{*}$ : significant at $\mathrm{p}=0.05 ;{ }^{* *}$ : significant at $\mathrm{p}=0.01{ }^{* * *}$ : significant at $\mathrm{p}=0.001$. 
cv. Rouge (respectively $510 \%$ and $3469 \%$ of that of the control) than in the salt sensitive cv. Locale (respectively $278 \%$ and $2921 \%$ at 30 and $90 \mathrm{mM} \mathrm{NaCl}$ ) in leaves. In roots, the same tendency was observed with an increase corresponding to $4161 \%$ and $5312 \%$ of that of the control for the salt-resistant cv. Rouge and to $1072 \%$ and $1539 \%$ for the salt-sensitive cv. Locale.

A two-ways ANOVA showed a significant effect of $\mathrm{NaCl}(\mathrm{p}<0.001)$ only for root $\mathrm{K}^{+}$concentrations; no significant difference was observed between the two cultivars in leaves and roots $\mathrm{K}^{+}$concentrations and no interaction between $\mathrm{NaCl}$ concentrations and cultivars (Table 3 ). However, data revealed a slight increase $(4 \%)$ of $\mathrm{K}^{+}$concentration in leaves of the salt resistant cv. Rouge at $30 \mathrm{mM} \mathrm{NaCl}$ followed by a slight decrease (5.5\%) at $90 \mathrm{mM} \mathrm{NaCl}$ while a continuous decrease (6\% and $9 \%$ respectively with 30 and $90 \mathrm{mM} \mathrm{NaCl}$ ) was observed for the salt sensitive cv. Locale (Figure 2). In roots, a continuous decrease was observed in both cultivars and such a decrease was more accentuated in roots of the salt-resistant cv. Rouge than in salt-sensitive cv. Locale. Thus, the reduction of $\mathrm{K}^{+}$content by salt stress was, from a relative point of view, less accentuated in leaves of the salt-resistant cv. Rouge than the salt-sensitive cv. Locale whereas an opposite tendency was observed in roots. A two-ways ANOVA also showed a significant reduction of $\mathrm{Ca}^{2+}$ concentrations in both cultivars in leaves $(\mathrm{p}<$ $0.001)$ and in roots $(\mathrm{p}<0.01)$ under salt stress. However, the one-way ANOVA revealed that the reduction was significant $(\mathrm{p}<0.05)$ only in leaves and roots of the salt-resistant cv. Rouge (Figure 3 ). Moreover, the salt sensitive cv. Locale presented the highest $\mathrm{Ca}^{2+}$ concentrations in both leaves and roots at all $\mathrm{NaCl}$ concentrations used.

A two-ways ANOVA showed a significant reduction of $\mathrm{Mg}^{2+}$ concentrations in leaves of both cultivars $(\mathrm{p}<0.05)$ and a significant difference was recorded between cultivars $(\mathrm{p}<0.01)$ for leaves $\mathrm{Mg}^{2+}$ concentrations (Table 3 ). The reduction of leaf $\mathrm{Mg}^{2+}$ concentration under salt-stress was more accentuated in the salt sensitive cv. Locale (Figure 4) and only a slight increase were observed at 30 $\mathrm{mM} \mathrm{NaCl}$ for the salt-resistant cultivar. For roots $\mathrm{Mg}^{2+}$ concentrations, a significant interaction $(\mathrm{p}<0.05)$ was observed between stress and cultivars. The one way ANOVA revealed that the reduction of roots $\mathrm{Mg}^{2+}$ concentration under salt-stress was significant only in the salt sensitive cv. Locale. A slight increase was observed at $90 \mathrm{mM} \mathrm{NaCl}$ for the salt-resistant cultivar (Figure 4). However, the salt sensitive $\mathrm{cv}$. Locale presented the highest $\mathrm{Mg}^{2+}$ concentrations in both leaves and roots at all $\mathrm{NaCl}$ concentrations used (except $90 \mathrm{mM}$ in roots). Thus, the effect of stress on $\mathrm{Mg}^{2+}$ content was more accentuated in the salt-sensitive $\mathrm{cv}$. Locale than in the salt-resistant cv. Rouge either in leaves or in roots but the salt resistant cultivar Rouge accumulated less $\mathrm{Mg}^{2+}$ in both leaves and roots.

\subsection{Free Proline and Soluble Sugars Accumulation}

Salt-resistant cultivar Rouge showed higher proline (Figure 5) and soluble sugars (Figure 6) content both in leaves and roots compared to salt-sensitive Locale in 


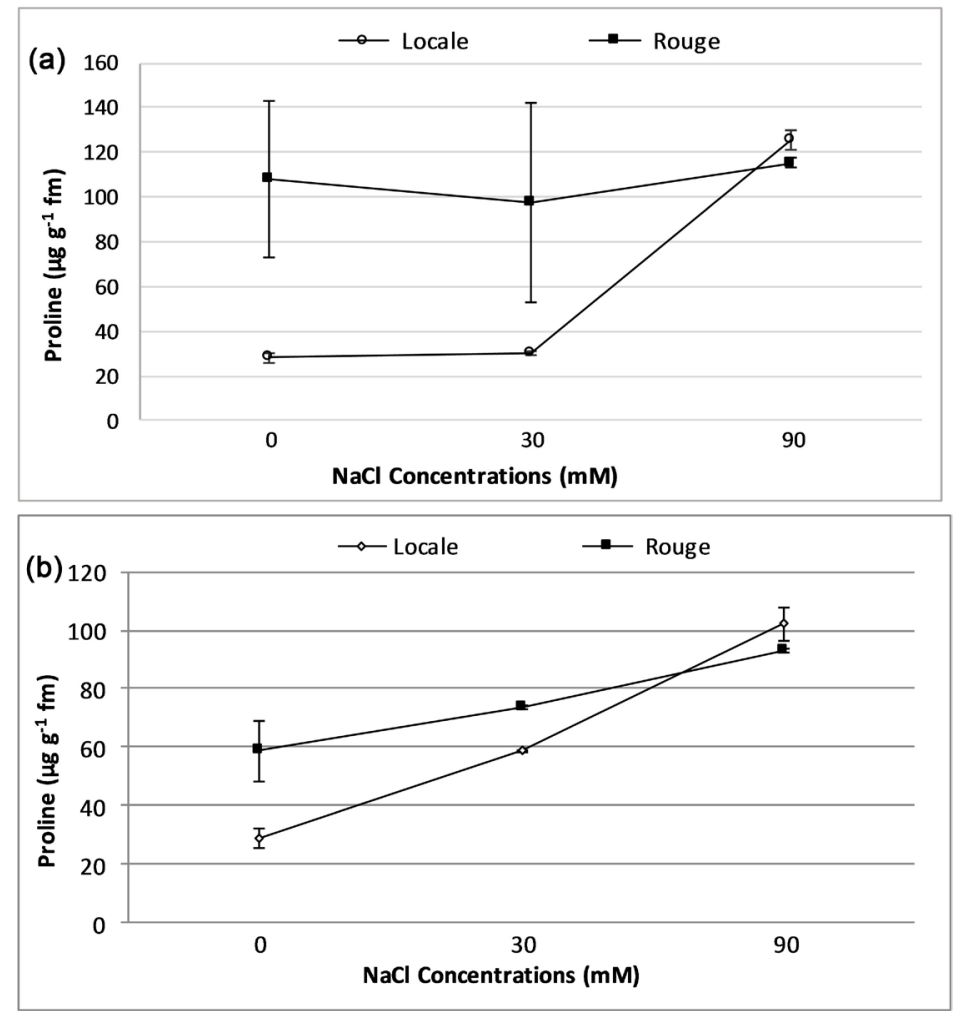

Figure 5. Effect of $\mathrm{NaCl}$ salt stress on proline content in two cultivars of amaranth after 2 weeks: (a) leaves; (b) Roots.
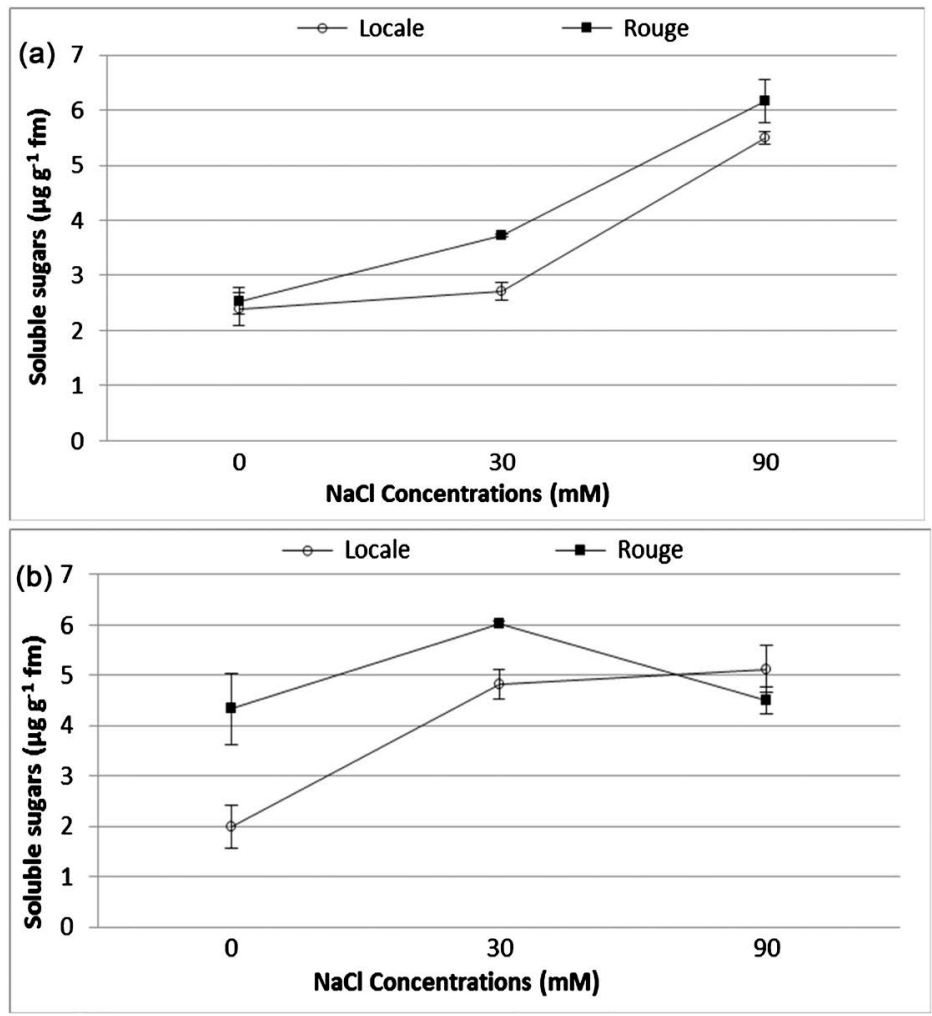

Figure 6. Effect of $\mathrm{NaCl}$ salt stress on soluble sugars content in two cultivars of amaranth after 2 weeks: (a) leaves; (b) Roots. 
absence of $\mathrm{NaCl}$. In the presence of $\mathrm{NaCl}$, free proline increased in leaves $(7.75 \%$ and $345 \%$ respectively at 30 and $90 \mathrm{mM} \mathrm{NaCl})$ and roots $(103.6 \%$ and $255 \%$ respectively at 30 and $90 \mathrm{mM} \mathrm{NaCl}$ ) of the salt-sensitive cv. Locale. A two-way ANOVA revealed significant $(\mathrm{p}<0.01)$ effect of $\mathrm{NaCl}$ and a significant $(\mathrm{p}<0.05)$ difference between cultivars for both leaves and roots proline content under salt stress and no interaction (leaves) and a significant interaction $(\mathrm{p}<0.01)$ between $\mathrm{NaCl}$ concentrations and cultivars (Table 3 ). These results indicated that the increase of free proline content under salt stress was more accentuated in both leaves and roots of the salt-sensitive cv. Locale than the salt resistant Rouge. However, the salt resistant cv. Rouge presented the highest proline concentrations in both leaves and roots at the lowest $\mathrm{NaCl}$ concentrations used ( 0 and 30 $\mathrm{mM} \mathrm{NaCl}$ ) whereas an opposite tendency was observed at the highest $\mathrm{NaCl}$ concentration used $(90 \mathrm{mM})$.

In the presence of $\mathrm{NaCl}$, soluble sugars markedly increased in leaves of both cultivars (Figure 6). A two-way ANOVA revealed that $\mathrm{NaCl}$ effect on leaves soluble sugars content was significant $(\mathrm{p}<0.001)$ in both cultivars with a significant difference $(\mathrm{p}<0.01)$ between them and no interaction between $\mathrm{NaCl}$ concentrations and cultivars. The increase of leaf soluble sugars content under salt stress was more accentuated in the salt-resistant cultivar than the salt sensitive one. For roots soluble sugars content, a two-way ANOVA revealed a significant $(\mathrm{p}<0.001)$ effect of salt-stress, a significant difference $(\mathrm{p}<0.05)$ between cultivars and a significant interaction $(\mathrm{p}<0.05)$ between salt stress and cultivars (Table 3). The one-way ANOVA for each cultivar revealed that the effect of $\mathrm{NaCl}$ stress on roots soluble sugars content was significant $(\mathrm{p}<0.001)$ at all $\mathrm{NaCl}$ concentrations used in the salt-sensitive cv. Locale whereas it was non-significant in the salt resistant cv. Rouge whatever the $\mathrm{NaCl}$ dose (Figure 6). Moreover, the salt resistant cultivar Rouge presented the highest soluble sugars concentration in both leaves and roots at all $\mathrm{NaCl}$ concentrations used (except in roots at $90 \mathrm{mM} \mathrm{NaCl}$ ).

\section{Discussion}

Our results revealed that plant growth reduction due to $\mathrm{NaCl}$ stress was more accentuated in the salt-sensitive Locale compared to the salt-resistant Rouge confirming the salt-resistance status of both cultivars as previously reported [42]. Salinity classically induced cell dehydration at low water potential, nutritional imbalance caused by the interference of saline ions with essential nutrients in both uptake and translocation processes and toxicity due to the high accumulation of $\mathrm{Na}^{+}$and $\mathrm{Cl}^{-}$in the cytoplasm. No changes in plant water content were observed in our cultivars indicating that water content parameter is not the main aspect of salt stress effect in these cultivars, corroborating our previous finding in the cultivar Locale [43] [44].

Ion homeostasis and compartmentalization in addition to ion transport and uptake are some of the principle physiological mechanisms developped by plant 
in order to survive in soils with high salt concentration [50]. Thus, Maintaining ion homeostasis can be particularly challenging for plants under saline conditions, as the accumulation of toxic ions (i.e. $\mathrm{Na}^{+}$) can perturb the plant's ability to control accumulation of other ions. In most species, $\mathrm{Na}^{+}$appears to accumulate to toxic levels before $\mathrm{Cl}^{-}$does [51] and $\mathrm{Cl}^{-}$is considered less toxic than $\mathrm{Na}^{+}$ [52]. Thus, we focus here on $\mathrm{Na}^{+}$, because reducing $\mathrm{Na}^{+}$in the shoot, while maintaining $\mathrm{K}^{+}$homeostasis, is a key component of salinity tolerance in many crops [53]. Plants of the two cultivars accumulated high amounts of $\mathrm{Na}^{+}$in leaves when exposed to $\mathrm{NaCl}$. Our results revealed that salt-resistant Rouge accumulated more $\mathrm{Na}^{+}$than the salt-sensitive Locale in leaves and roots. These results indicated that $\mathrm{Na}^{+}$ions toxicity should play a key role in $\mathrm{NaCl}$ adverse effects on amaranth plants growth. Thus, the detrimental effects of $\mathrm{Na}^{+}$on growth are more accentuated in aerial part (RHG and SFM, mainly) of the sensitive Locale compared to $\mathrm{cv}$. Rouge plants. It may be hypothesized that accumulation of these ions in leaves apparently did not cause much injury to the aerial part in resistant cultivar. Leaf $\mathrm{Na}^{+}$exclusion has been reported as a mechanism for salt tolerance in numerous species [10]. $\mathrm{Na}^{+}$exclusion from leaves is associated with salt tolerance in several crops such as rice, durum wheat, bread wheat, barley, sugarcane, pearl millet [21] [32] [53] and references therein]. However, the salt resistance of the amaranth cultivar Rouge was not associated to $\mathrm{Na}^{+}$exclusion as reported in some cultivars of other plant species including maize [54] and sugarcane [38]. The critical point of plant salt tolerance was to keep $\mathrm{Na}^{+}$and $\mathrm{Cl}^{-}$ concentrations in the cytoplasm below toxic levels [10] by partitioning these ions within cells so that concentrations in the cytoplasm are kept low [52]. Thus, it is logical to infer that much of the $\mathrm{Na}^{+}$accumulated by the salt-resistant cultivar Rouge are sequestrated in the vacuoles or extruded to the apoplasm [10] causing very little or no interference with the cellular metabolism necessary for sustained growth. Salt-resistance cv. Rouge appeared as a toxic ions includer since its accumulated more $\mathrm{Na}^{+}$in leaves (and roots) in presence of $\mathrm{NaCl}$ than the salt sensitive cultivar.

In the presence of $\mathrm{NaCl}$, the salt-resistant Rouge maintained high amounts of $\mathrm{K}^{+}$in leaves. In plants, higher $\mathrm{K}^{+}$was considered as an important indicator of salt resistance [16] as potassium ions are known to be a major component of osmotic adjustment during stress [55]. $\mathrm{K}^{+}$concentrations in plants usually decrease with $\mathrm{NaCl}$ treatment [56]. In the presence of $\mathrm{NaCl}, \mathrm{K}^{+}$concentration decreased significantly only in roots although the decrease was more accentuated in leaves of the salt-sensitive cultivar Locale than the salt-resistant cultivar Rouge. It is well known that $\mathrm{Na}^{+}$and $\mathrm{K}^{+}$cations compete for uptake by membrane transporters [12] and $\mathrm{K}^{+}$deficiency relates to plants productivity as it is involved in important physiological processes, such as osmotic adjustment during stress [55] and stomatal opening [57]. Thus, the salt resistance of the cultivar Rouge could partly be due to the internal maintenance of high concentrations of $\mathrm{K}^{+}$in leaves in the presence of high amount of $\mathrm{Na}^{+}$in the medium. 
Several reports suggested that apoplastic $\mathrm{Ca}^{2+}$ directly alleviates symptoms produced by mineral toxicities under salt stress. In this study, salt stress induced a significant reduction in both leaves and roots $\mathrm{Ca}^{2+}$ concentration in both cultivars but the reduction was more accentuated in both leaves and roots of the salt-resistant $\mathrm{cv}$. Rouge than the salt-sensitive $\mathrm{cv}$. Locale and the salt-resistant cultivar accumulated less $\mathrm{Ca}^{2+}$ in both leaves and roots than the salt-sensitive one. This result indicated that $\mathrm{Ca}^{2+}$ uptake and transport were not implicated in the salt-resistance of the cultivar Rouge or that $\mathrm{Ca}^{2+}$ content was sufficient to provide adequate protection to salinity in this cultivar. It stated that high levels of $\mathrm{Na}^{+}$inhibits $\mathrm{Mg}^{2+}$ in leaves [29] [30]. In this study, the reduction of $\mathrm{Mg}^{2+}$ content under salt stress was more accentuated in the salt-sensitive cultivar Locale than in the salt-resistant cv. Rouge either in leaves or in roots. Thus, in Amaranthus cruentus cultivars, $\mathrm{Mg}^{2+}$ accumulation appears as an indicator of salt resistance.

Biosynthesis of osmoprotectants and compatible solutes are among the principle physiological and biochemical mechanisms developped by plants in order to survive in soils with high salt concentration [50]. Proline and soluble sugars are the main members of these osmoprotectants and compatible solutes. Proline is thought to be involved in osmotic adjustment but it may also directly act to protect cellular structures and enzymes or scavenge reactive oxygen species [58]. In african rice species $O$. glaberrima cultivars, Prodjinoto et al. [45] suggested that proline does not assume key functions in salinity resistance or that the signaling pathway leading to proline over-synthesis is still not triggered in salt-resistant which significantly accumulated lower proline concentrations than salt-sensitive one. A similar situation was reported in $O$. sativa where salt-resistant cultivars accumulated lower proline concentrations than salt-sensitive ones [17] as well as in sugarcane [37] [38]. We demonstrated that the increase of free proline content under salt stress was more accentuated in leaves and roots of the salt-sensitive cultivar Locale than the salt resistant Rouge. Thus, in Amaranthus cruentus cultivars, proline should be regarded not as an indicator of salt resistance but as a typical "stress response" solute as reported in tomato [48].

Sugars are also considered to play a major role in osmoregulation under abiotic stress conditions [59]. According to [60], total soluble carbohydrates are important solutes that accumulate in cytosol under salt stress and may thus contribute to plant survival. Our results revealed that $\mathrm{NaCl}$ induced an increase in soluble sugars content both in leaves and in roots of both cultivars. Resistant cv. Rouge accumulated more soluble sugars than the sensitive Locale in leaves; this tendency is reversed in the roots. Salt stress effects result mainly in an increase of soluble sugars content in both leaves and roots in many plants and the most tolerant cultivars frequently accumulated more soluble sugars as reported for sugarcane [22] [37] [38]. According to [61], among the organic osmotica, sugars contribute by more than $50 \%$ to the total osmotic potential in glycophytes exposed to salt stress. The fact that the most resistant cultivar accumulates more 
soluble sugars under salt stress especially in leaves seems to indicate that soluble sugars play a role of an osmo-protector in salt resistance of Amaranthus cruentus.

\section{Conclusion}

The present study revealed that $\mathrm{Na}^{+}$toxicity is implied in salt effect in Amaranthus cruentus plants and that cultivar Rouge salt-resistance is due to a tolerance mechanism. This study showed that $\mathrm{K}^{+}$and $\mathrm{Mg}^{2+}$ play an important role in Amaranthus cruentus plant salt resistance and that organic solutes such as soluble sugars would be directly involved in salt resistance in this species. Proline is not directly involved in salt resistance in Amaranthus cruentus plants.

\section{Acknowledgements}

The authors thank Mr. Armel Mensah from Market Gardening Crops Program of the Benin National Institute for Agricultural Research (INRAB) for seeds providing and Prof. Hounnankpon Yédomonhan from the National Herbarium of Benin for Amaranth species identification. This work was supported by the Programme "Formation des Formateurs" of the University of Abomey-Calavi, Republic of Benin.

\section{Conflicts of Interest}

The authors declare no conflicts of interest regarding the publication of this paper.

\section{References}

[1] Gunes, A., Inal, A., Alpaslan, M., Eraslan, F., Bagci, E.G. and Cicek, N. (2007) Salicylic Acid Induced Changes on Some Physiological Parameters Symptomatic for Oxidative Stress and Mineral Nutrition in Maize (Zea mays L.) Grown under Salinity. Journal of Plant Physiology, 164, 728-736. https://doi.org/10.1016/j.jplph.2005.12.009

[2] Khan, M.N., Siddiqui, M., Mohammad, F., Naeem, M. and Khan, M.M. (2010) Calcium Chloride and Gibberellic Acid Protect Linseed (Linum usitatissimum L.) from $\mathrm{NaCl}$ Stress by Inducing Antioxidative Defence System and Osmoprotectant Accumulation. Acta Physiologiae Plantarum, 32, 121-132. https://doi.org/10.1007/s11738-009-0387-Z

[3] Lutts, S., Kinet, J.M. and Bouharmont, J. (1995) Changes in Plant Response to $\mathrm{NaCl}$ during Development of Rice (Oryza sativa L.) Varieties Differing in Salinity Resistance. Journal of Experimental Botany, 46, 1843-1852.

https://doi.org/10.1093/jxb/46.12.1843

[4] Gandonou, C.B. and Skali Senhaji, N. (2015) Sugarcane (Saccharum sp.) Salt Tolerance at Various Developmental Levels. In: Chakraborty, U. and Chakraborty, B., Eds., Abiotic Stresses in Crop Plants, CABI Publishing, Wallingford.

[5] Wouyou, D.A. (2017) Réponse de l'amarante (Amaranthus cruentus L.) à la salinité: Caractérisation de cultivars, mécanisme physiologique de résistance et qualité nutritionnelle des feuilles. Thèse de doctorat, 163/EDSVT/2017, Université d'Abomey-Calavi, Bénin, 120 p. 
[6] Juan, M., Rivero, R.M., Romero, L. and Ruiz, J.M. (2005) Evaluation of Some Nutritional and Biochemical Indicators in Selecting Salt-Resistant Tomato Cultivars. Environmental and Experimental Botany, 54, 193-201. https://doi.org/10.1016/j.envexpbot.2004.07.004

[7] Siddiqui, M., Mohammad, F., Khan, M.N., Al-Whaib, M.H. and Bahkali, A.H.A. (2010) Nitrogen in Relation to Photosynthetic Capacity and Accumulation of Osmoprotectant and Nutrients in Brassica Genotypes Grown under Salt Stress. Agricultural Sciences in China, 9, 671-680. https://doi.org/10.1016/S1671-2927(09)60142-5

[8] Ashraf, M. and McNeilly, T. (2004) Salinity Tolerance in Brassica Oilseeds. Critical Reviews in Plant Sciences, 23, 157-174. https://doi.org/10.1080/07352680490433286

[9] Manaa, A., Ben Ahmed, H., Valot, B., Bouchet, J.P., Aschi-Smiti, S., Causse, M. and Faurobert, M. (2011) Salt and Genotype Impact on Plant Physiology and Root Proteome Variations in Tomato. Journal of Experimental Botany, 62, 2797-2813. https://doi.org/10.1093/jxb/erq460

[10] Chiconato, D.A., Cruz, F.J.R., da Silva, S.J.G., dos Santos, D.M.M. and Munns, R. (2019) Adaptation of Sugarcane (Saccharum officinarum L.) Plants to Saline Soil. Environmental and Experimental Botany, 162, 201-211. https://doi.org/10.1016/j.envexpbot.2019.02.021

[11] Maggio, A., Raimondi, G. and Martino A De Pascale, S. (2007) Salt Stress Response in Tomato beyond the Salinity Tolerance Threshold. Environmental and Experimental Botany, 59, 276-282. https://doi.org/10.1016/j.envexpbot.2006.02.002

[12] Deinlein, U., Stephan, A.B., Horie, T., Luo, W., Xu, G. and Schroeder, J.I. (2014) Plant Salt-Tolerance Mechanisms. Trends in Plant Science, 6, 371-379. https://doi.org/10.1016/j.tplants.2014.02.001

[13] Munns, R. and Gilliham, M. (2015) Salinity Tolerance of Crops-What Is the Cost? New Phytologist, 208, 668-673. https://doi.org/10.1111/nph.13519

[14] Parihar, P., Singh, S., Singh, R., Singh, V.P. and Prasad, S.M. (2015) Effect of Salinity Stress on Plants and Its Tolerance Strategies: A Review. Environmental Science and Pollution Research, 22, 4056-4075. https://doi.org/10.1007/s11356-014-3739-1

[15] Abbasi, H., Jamil, M., Haq, A., Ali, S., Ahmad, R., Malik, Z. and Parveen (2016) Salt Stress Manifestation on Plants, Mechanism of Salt Tolerance and Potassium Role in Alleviating It: A Review. Zemdirbyste-Agriculture, 103, 229-238. https://doi.org/10.13080/z-a.2016.103.030

[16] Shabala, S. and Pottosin, I. (2014) Regulation of Potassium Transport in Plants Under Hostile Conditions: Implications for Abiotic and Biotic Stress Tolerance. Physiologia Plantarum, 151, 257-279. https://doi.org/10.1111/ppl.12165

[17] Lutts, S., Kinet, J.M. and Bouharmont, J. (1996) Effects of Salt Stress on Growth, Mineral Nutrition and Proline Accumulation in Relation to Osmotic Adjustment in Rice (Oryza sativa L.) Cultivars Differing in Salinity Resistance. Plant Growth Regulation, 19, 207-218. https://doi.org/10.1007/BF00037793

[18] Lutts, S., Kinet, J.M. and Bouharmont, J. (1996) Effects of Various Salts and of Mannitol on Ion and Proline Accumulation in Relation to Osmotic Adjustment in Rice (Oryza sativa L.) Callus Cultures. Journal of Plant Physiology, 149, 186-195. https://doi.org/10.1016/S0176-1617(96)80193-3

[19] Almansouri, M., Kinet, J.M. and Lutts, S. (1999) Compared Effects of Sudden and Progressive Impositions of Salt Stress in Three Durum Wheat (Triticum durum Desf.) Cultivars. Journal of Plant Physiology, 154, 743-752. https://doi.org/10.1016/S0176-1617(99)80253-3 
[20] Ashraf, M. and Ahmad, S. (2000) Influence of Sodium Chloride on Ion Accumulation, Yield Components and Fibre Characteristics in Salt-Tolerant and Salt-Sensitive Lines of Cotton (Gossypium hirsutum L.). Field Crops Research, 66, 115-127. https://doi.org/10.1016/S0378-4290(00)00064-2

[21] Melchiorre, M., Quero, G.E., Parola, R., Racca, R., Trippi, V.S. and Lascano, R. (2009) Physiological Characterization of Four Model Lotus Diploid Genotypes: L. japonicus (MG20 and Gifu), L. filicaulis, and L. burttii under Salt Stress. Plant Science, 115, 618-628. https://doi.org/10.1016/j.plantsci.2009.09.010

[22] Gandonou, Ch., Abrini, J., Idaomar, M. and Skali-Senhaji, N. (2005) Response of Sugarcane (Saccharum sp.) Varieties to Embryogenic Callus Induction and in Vitro Salt Stress. African Journal of Biotechnology, 4, 350-354.

[23] Ashraf, M. and Waheed, A. (1993) Responses of Some Local/Exotic Accessions of Lentil (Lens culinaris Medic.) to Salt Stress. Journal of Agronomy and Soil Science, 170, 103-112. https://doi.org/10.1111/j.1439-037X.1993.tb01063.x

[24] Santa-Maria, G.E. and Epstein, H. (2001) Potassium/Sodium Selectivity in Wheat and the Amphiploid Cross Wheat X Lophopyrum elongatum. Plant Science, 160, 523-534. https://doi.org/10.1016/S0168-9452(00)00419-2

[25] Ashraf, M., Rahmatullah, Afzal, M., Ahmed, R., Mujeeb, F., Sarwar, A. and Ali, L. (2010) Alleviation of Detrimental Effects of $\mathrm{NaCl}$ by Silicon Nutrition in Salt-Sensitive and Salt-Tolerant Genotypes of Sugarcane (Saccharum officinarum L.). Plant and Soil, 326, 381-391. https://doi.org/10.1007/s11104-009-0019-9

[26] Jiang, Y. and Huang, B. (2001) Effects of Calcium on Antioxidant Activities and Water Relations Associated with Heat Tolerance in Two Cool-Season Grasses. Journal of Experimental Botany, 52, 341-349. https://doi.org/10.1093/jexbot/52.355.341

[27] Hirschi, K.D. (2004) The Calcium Conundrum. Both Versatile Nutrient and Specific Signal. Plant Physiology, 136, 2438-2442. https://doi.org/10.1104/pp.104.046490

[28] Song, J.Y. and Roe, J.H. (2008) The Role and Regulation of Trxl, a Cytosolic Thioredoxin in Schizosaccharomyces pombe. The Journal of Microbiology, 46, 408-414. https://doi.org/10.1007/s12275-008-0076-4

[29] Turan, M.A., Turkmen, N. and Taban, N. (2007) Effect of $\mathrm{NaCl}$ on Stomacal Resistance and Proline, Chlorophyll, $\mathrm{Na}, \mathrm{Cl}$ and $\mathrm{K}$ Concentrations of Lentil Plants. Journal of Agronomy, 6, 378-381. https://doi.org/10.3923/ja.2007.378.381

[30] Hand, M.J., Taffouo, V.D., Nouck, A.E., Kitio, P.J., Nyemene, K.P.J., Tonfack, B.L., Meguekam, T.L. and Youmbi, E. (2017) Effects of Salt Stress on Plant Growth, Nutrient Partitioning, Chlorophyll Content, Leaf Relative Water Content, Accumulation of Osmolytes and Antioxidant Compounds in Pepper (Capsicum annuum L.) Cultivars. Notulae Botanicae HortiAgrobotanici, 45, 481-490. https://doi.org/10.15835/nbha45210928

[31] Singh, M., Kumar, J., Singh, V.P. and Prasad, S. (2014) Proline and Salinity Tolerance in Plants. Biochemistry and Pharmacology, 3, e170. https://doi.org/10.4172/2167-0501.1000e170

[32] Gharsallah, C., Fakhfakh, H., Grubb, D. and Gorsane, F. (2016) Effect of Salt Stress on Ion Concentration, Proline Content, Antioxidant Enzyme Activities and Gene Expression in Tomato Cultivars. AoB Plants, 8, plw055. https://doi.org/10.1093/aobpla/plw055

[33] Liang, X., Zhang, L., Natarajan, S.K. and Becker, D.F. (2013) Proline Mechanisms of Stress Survival. Antioxidants and Redox Signaling, 19, 998-1011.

https://doi.org/10.1089/ars.2012.5074 
[34] Ben Rejeb, K., Abdelly, C. and Savouré, A. (2014) How Reactive Oxygen Species and Proline Face Stress Together. Plant Physiology and Biochemistry, 80, 278-284. https://doi.org/10.1016/j.plaphy.2014.04.007

[35] Gandonou, C.B., Idaomar, M., Abrini, J. and Skali Senhaji, N. (2005b) Effects of $\mathrm{NaCI}$ on Growth, Ions and Proline Accumulation in Sugarcane (Saccharum sp.) Callus Culture. Belgian Journal of Botany, 138, 173-180.

[36] Watanabe, S., Kojima, K., Ide, Y. and Sasaki, S. (2000) Effects of Saline and Osmotic Stress on Proline and Sugar Accumulation in Populus euphratica in Vitro. Plant Cell, Tissue and Organ Culture, 63, 199-206. https://doi.org/10.1023/A:1010619503680

[37] Gandonou, C.B., Errabii, T., Idaomar, M., Abrini, J. and Skali Senhaji, N. (2006) Selection of Callus Cultures of Sugarcane (Saccharum sp.) Tolerant to NaCI and Their Response to Salt Stress. Plant Cell, Tissue and Organ Culture, 87, 9-16. https://doi.org/10.1007/s11240-006-9113-3

[38] Gandonou, C.B., Bada, F., Abrini, J. and Skali Senhaji, N. (2011) Free Proline, Soluble Sugars and Soluble Proteins Concentrations as Affected by Salt Stress in Two Sugarcane (Saccharum sp.) Cultivars Differing in Their Salt Tolerance. International Journal of Biological and Chemical Sciences, 5, 1488-1493. https://doi.org/10.4314/ijbcs.v5i6.23

[39] Omami, E.N. (2005) Response of Amaranth to Salinity Stress. PhD Dissertation, University of Pretoria, Pretoria, 235 p.

[40] Omami, E.N., Hammes, P.S. and Robbertse, P.J. (2006) Differences in Salinity Tolerance for Growth and Water-Use Efficiency in Some Amaranth (Amaranthus spp.) Genotypes. New Zealand Journal of Crop Horticultural Science, 34, 11-22. https://doi.org/10.1080/01140671.2006.9514382

[41] Wouyou, A., Gandonou, C.B., Montcho, D., Kpinkoun, J., Kinsou, E., Assogba Komlan, F. and Gnancadja, S.L. (2016) Salinity Resistance of Six Amaranth (Amaranthus sp.) Cultivars Cultivated in Benin at Germination Stage. International Journal of Plant and Soil Science, 11, 1-10. https://doi.org/10.9734/IJPSS/2016/25892

[42] Wouyou, A., Gandonou, C.B., Assogba Komlan, F., Montcho, D., Zanklan, S.A., Lutts, S. and Gnancadja, S.L. (2017) Salinity Resistance of Five Amaranth (Amaranthus cruentus) Cultivars at Young Plants Stage. International Journal of Plant and Soil Science, 14, 1-11. https://doi.org/10.9734/IJPSS/2017/31611

[43] Gandonou, C.B., Prodjinoto, H., Zanklan, S.A., Wouyou, A.D., Lutts, S., Montcho, D.H., Assogba Komlan, F. and Mensah, A.C.G. (2018) Effects of Salinity Stress on Growth in Relation to Gas Exchanges Parameters and Water Status in Amaranth (Amaranthus cruentus). International Journal of Plant Physiology and Biochemistry, 10, 19-27.

[44] Went, F.E. (1957) The Experimental Control of Plant Growth, Chronica Botanica Co., Mattham.

[45] Prodjinoto, H., Gandonou, C. and Lutts, S. (2018) Screening for Salinity Tolerance at the Young Seedling Stage in Oryza glaberrima Steud.: A Morphophysiological Approach. African Journal of Agricultural Research, 13, 561-573. https://doi.org/10.5897/AJAR2017.12654

[46] Bates, I.S., Waldern, R.P. and Teare, I.D. (1973) Rapid Determination of Free Proline for Mater Stress Studies. Plant and Soil, 39, 205-207. https://doi.org/10.1007/BF00018060

[47] Yemm, W. and Willis, A.J. (1954) The Estimation of Carbohydrates in Plant Ex- 
tracts by Anthrone. Biochemical Journal, 57, 508-514. https://doi.org/10.1042/bj0570508

[48] Manaa, A., Gharbi, E., Mimouni, H., Wasti, S., Aschi-Smiti, S., Lutts, S. and Ben Ahmed, H. (2014) Simultaneous Application of Salicylic Acid and Calcium Improves Salt Tolerance in Two Contrasting Tomato (Solanum lycopersicum) Cultivars. South African Journal of Botany, 95, 32-39. https://doi.org/10.1016/j.sajb.2014.07.015

[49] JMP Pro SAS Institute (2009) JMP ${ }^{\bowtie}$ 8. User Guide, Second Edition. SAS Institute Inc., Cary.

[50] Gupta, B. and Huang, B. (2014) Mechanism of Salinity Tolerance: Physiological, Biochemical and Molecular Characterization. International Journal of Genomics, 2014, Article ID: 701596. https://doi.org/10.1155/2014/701596

[51] Negrão, S., Schmöckel, S.M. and Tester, M. (2017) Evaluating Physiological Responses of Plants to Salinity Stress. Annals of Botany, 119, 1-11. https://doi.org/10.1093/aob/mcw191

[52] Munns, R. and Tester, M. (2008) Mechanism of Salinity Tolerance. Annual Review of Plant Biology, 59, 651-681. https://doi.org/10.1146/annurev.arplant.59.032607.092911

[53] Munns, R. (2011) Plant Adaptations to Salt and Water Stress: Differences and Commonalities. Advances in Botanical Research, 57, 1-32. https://doi.org/10.1016/B978-0-12-387692-8.00001-1

[54] Alberico, G.J. and Cramer, G.R. (1993) Is the Salt Tolerance of Maize Related to Sodium Exclusion? I. Preliminary Screening of Seven Cultivars. Journal of Plant Nutrition, 16, 2289-2303. https://doi.org/10.1080/01904169309364687

[55] Wu, S.-J., Ding, L. and Zhu, J.-K. (1996) SOS 1, a Genetic Locus Essential for Salt Tolerance and Potassium Acquisition. Plant Cell, 8, 617-627. https://doi.org/10.2307/3870339

[56] Shabala, S. and Cuin, T.A. (2008) Potassium Transport and Plant Salt Tolerance. Physiologia Plantarum, 133, 651-669. https://doi.org/10.1111/j.1399-3054.2007.01008.x

[57] Benito, B., Haro, R., Amtmann, A., Cuin, T.A. and Dreyer, I. (2014) The Twins K ${ }^{+}$ and $\mathrm{Na}^{+}$in Plants. Journal of Plant Physiology, 171, 723-731. https://doi.org/10.1016/j.jplph.2013.10.014

[58] Mansour, M.M.F. and Ali, E.F. (2017) Evaluation of Proline Functions in Saline Conditions. Phytochemistry, 140, 52-68. https://doi.org/10.1016/j.phytochem.2017.04.016

[59] Fallon, K.M. and Phillips, R. (1989) Responses to Water Stress in Adapted and Unadapted Carrot Cell Suspension Cultures. Journal of Experimental Botany, 40, 681-687. https://doi.org/10.1093/jxb/40.6.681

[60] Rejšková, A.B., Lenka, P., Eva, S. and Helena, L. (2007) The Effect of Abiotic Stresses on Carbohydrate Status of Olive Shoots (Olea europaea L.) under in Vitro Conditions. Journal of Plant Physiology, 164, 174-184. https://doi.org/10.1016/j.jplph.2005.09.011

[61] Cram, W.J. (1976) Negative Feedback Regulation of Transport in Cells. The Maintenance of Turgor, Volume and Nutrient Supply. In: Luttge, U. and Pitman, M.G., Eds., Encyclopedia of Plant Physiology, New Series, 2, Springer-Verlag, Berlin, 284-316. https://doi.org/10.1007/978-3-642-66227-0 11 


\section{Abbreviations}

$\begin{array}{ll}\text { RHG } & \text { Relative Height Growth } \\ \text { SFM } & \text { Shoot Fresh Mass } \\ \text { SDM } & \text { Shoot Dry Mass } \\ \text { RFM } & \text { Root Fresh Mass } \\ \text { RDM } & \text { Root Dry Mass }\end{array}$

